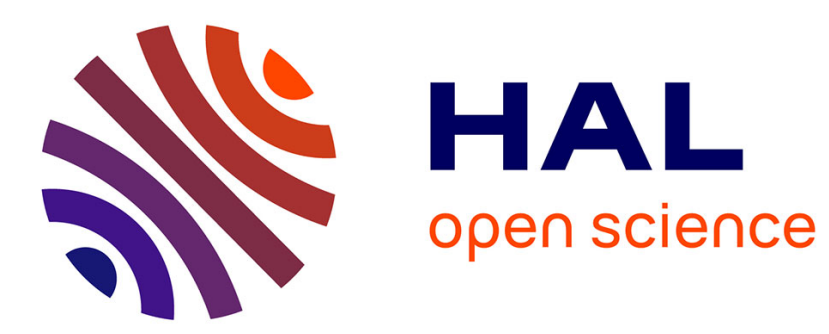

\title{
Simple deterministic model of the hydraulic buffer effect in septic tanks
}

Nicolas Forquet, Matthieu Dufresne

\section{To cite this version:}

Nicolas Forquet, Matthieu Dufresne. Simple deterministic model of the hydraulic buffer effect in septic tanks. Water and Environment Journal, 2015, 29 (3), pp.360-364. 10.1111/wej.12114 . hal-01410206

\section{HAL Id: hal-01410206 \\ https://hal.science/hal-01410206}

Submitted on 16 May 2020

HAL is a multi-disciplinary open access archive for the deposit and dissemination of scientific research documents, whether they are published or not. The documents may come from teaching and research institutions in France or abroad, or from public or private research centers.
L'archive ouverte pluridisciplinaire $\mathbf{H A L}$, est destinée au dépôt et à la diffusion de documents scientifiques de niveau recherche, publiés ou non, émanant des établissements d'enseignement et de recherche français ou étrangers, des laboratoires publics ou privés. 


\section{Simple deterministic model of the hydraulic buffer effect in septic tanks}

3 Nicolas Forquet ${ }^{1}$ and Matthieu Dufresne ${ }^{2}$

\section{Abstract}

5 Septic tanks are widely used in on-site wastewater treatment systems. In addition to anaerobic pretreatment, hydraulic buffering is one of the roles attributed to septic tanks. However there is still no tool for assessing it, especially in dynamic conditions. For gravity fed-system, it could help both researchers and system designers. This technical note reports a simple mechanistic model based on the assumption of flow transition between the septic tank and the outflow pipe. The only parameter of this model was calibrated using CFD modeling for a wide range of discharge rates. The resulting model highlights that a septic tank plays a hydraulic buffer role when faced with sudden and large discharge flow but this role tends to disappear when input hydrographs are smoother. In those cases there is an observable lag between the input hydrograph and outflow hydrograph.

Key words: on-site wastewater treatment - septic tank - buffer effect - mechanistic modeling

\section{Introduction}

On-site wastewater systems usually consist of a septic tank followed by a treatment unit. In many countries (including the USA and France), treatment units are commonly gravity-fed from the outlet of the septic tank (e.g. a drainfield trench or vertical flow sand filter). Because flow at the outlet of a septic tank is not constant, the distribution over the surface of the treatment unit is rather uneven, especially in early filter operation (Bridson-Pateman et al., 2013; Gill et al., 2009). Flow variability stems mainly from household water usage patterns, but the septic tank also induces some flow modulation. The hydraulic buffer effect of septic tanks is often cited but to our knowledge there is still no method for quantifying it. It is often assumed that for the purposes of studying of long-term phenomena (like clogging of the treatment unit at month-long or year-long scale), the outflow can be considered constant (Winstanley \& Fowler, 2013). However, as we gain progressively more knowledge on the actual hydrograph produced by a household, it may be interesting to quantify how effectively the septic tank can buffer large inflow rates. This may be of particular interest for estimating the efficiency of gravity-driven distribution on secondary treatment unit and to eventually optimize it.

\footnotetext{
${ }^{1}$ Irstea, UR MALY, centre de Lyon-Villeurbanne, 5 rue de la Doua - CS 70077, 69626 Villeurbanne Cedex, France. nicolas.forquet@irstea.fr

${ }^{2}$ Ecole Nationale du Génie de l'Eau et de l'Environnement de Strasbourg, Laboratoire ICube (Université de Strasbourg, CNRS, INSA de Strasbourg, ENGEES), ICube, 2 rue Boussigault 67000 Strasbourg, France.
} 
Two possible approaches were identified: (i) using a tank model where the law governing outflow is obtained by a statistical learning or neural network method (Vazquez et al., 1999) or (ii) the overflow analogy. A statistical learning or neural network method is able to mimic complex hydraulic systems without the need to compile advanced knowledge of the constitutive elements. However, it requires a large dataset for model learning, which is not compatible with our needs. The overflow analogy is based on a simple mechanistic approach based on the assumption that critical flow occurs at the outlet of the septic tank. In this paper, we briefly present the model and its practical implementation, and then report selected results based on several hydrographs.

\section{Model presentation}

\section{Model equations}

Figure 1 presents a sketch of the usual design of a septic tank. The upstream section of the outflow pipe of a septic tank is a local maximum of the bottom profile. With no downstream influence (guaranteed by the large slope of the pipe, which is usually over $0.5 \%$; AFNOR, 2007), this configuration is responsible for producing critical flow (Hager 1999). Critical flow is the transition between subcritical flow (here, a nearly horizontal water surface with a very small velocity in the septic tank) and supercritical flow (here, a fast flow in the outflow pipe). The occurrence of critical flow guarantees a direct relationship between water level h in the tank and the outflow discharge $\left(\mathrm{Q}_{\text {out }}\right.$ $\left.\left[\mathrm{L}^{3} \mathrm{~T}^{-1}\right]\right)$. We used this relationship in association with a water mass balance in the septic tank to build a time-dependent model.

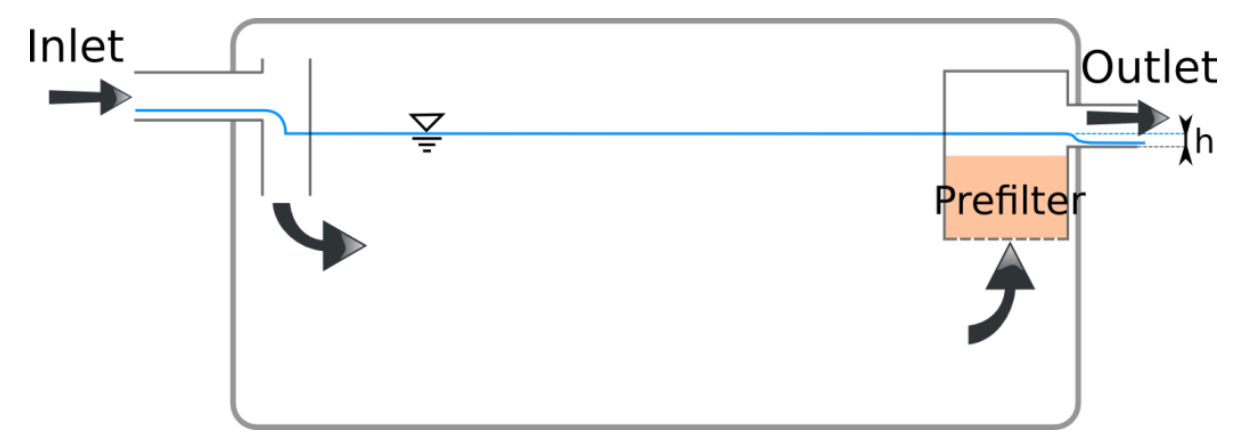

Figure 1. Sketch of the water flow through a septic tank

The discharge $Q_{\text {out }}$ corresponding to the critical water depth $h_{c}[\mathrm{~L}]$ can be evaluated considering a Froude number equal to unity (transition from subcritical to supercritical flow), according to:

$$
Q_{\text {out }}=S_{c} \sqrt{g D_{h c}}
$$

where $Q_{\text {out }}$ is outflow discharge $\left[\mathrm{L}^{3} \mathrm{~T}^{-1}\right], S_{c}$ is critical cross-section $\left[\mathrm{L}^{2}\right], g$ is gravitational acceleration [L T ${ }^{-2}$ ] and $D_{h c}$ is critical hydraulic diameter [L]. Both $S_{c}$ and $D_{h c}$ are linked to the critical water depth $\left(h_{c}\right)$ by relationships (Equations 2, 3 and 4) using the angle $\delta_{c}$ as illustrated in Figure 2. 
57

$59 \quad S_{c}=\frac{D^{2}}{4}\left(\delta_{c}-\sin \delta_{c} \cos \delta_{c}\right)$

60

61

68

$71 \Delta H=K \frac{Q_{\text {out }}^{2}}{2 g S_{c}^{2}}$

$D_{h c}=\frac{D\left(\delta_{c}-\sin \delta_{c} \cos \delta_{c}\right)}{4 \sin \delta_{c}}$

$h_{c}=\frac{D}{2}\left(1-\cos \delta_{c}\right)$

$$
\delta_{c}=a \cos \left(1-2 \frac{h_{c}}{D}\right)
$$

$$
H_{c}=h_{c}+\frac{Q_{o u t}^{2}}{2 g S_{c}^{2}}
$$
thus:

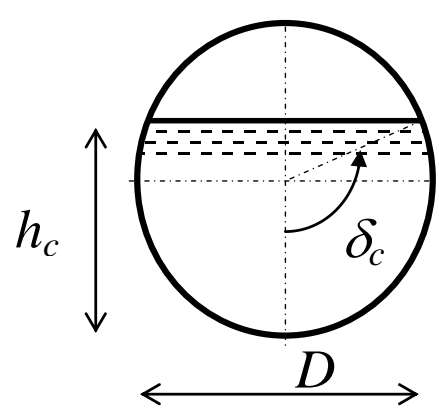

where $D$ is outlet pipe diameter [L]. The angle $\delta_{c}$ may be expressed as a function of $D$ and $h_{c}$ :

Equation 1 links the outflow discharge to the critical water depth in the outflow pipe. We are now seeking out a relationship between critical water depth $\left(h_{c}\right)$ and the water depth in the tank ( $h[\mathrm{~L}]$, measured from the invert of the outflow pipe). Knowing the critical water depth $\left(h_{c}\right)$, the critical energy head $H_{c}[\mathrm{~L}]$ can be calculated with the following expression.

The head loss $\Delta H[\mathrm{~L}]$ between the tank and the critical section can be evaluated as a local head loss,

The loss coefficient $K$ [-] was evaluated by CFD using the OpenFOAM software package (2013) for a $100 \mathrm{~mm}$ diameter pipe and a flow rate ranging from 0.10 to $1.50 \mathrm{~L} / \mathrm{s}$. The conclusion of the numerical simulations is that the loss coefficient $K$ is approximately 0.4 for the whole discharge range. Using this value and an estimation of the numerical uncertainty based on a grid sensitivity analysis, the uncertainty on the outflow discharge $\left(Q_{\text {out }}\right)$ for a given water depth $(h)$ was evaluated as $5 \%$. Finally, 
$h=H_{c}+\Delta H$

the water depth in the tank $(h)$ can be evaluated using equation 7 (Bernoulli equation written between the critical section and the tank where the velocity head is close to zero).

Based on equations 6 and 7, equation 8 can be rewritten as:

81

$$
h=h_{c}+(K+1) \frac{Q_{o u t}^{2}}{2 g S_{c}^{2}}
$$

Replacing $h_{c}$ and $S_{c}$ in equation (9) by expressions dependent solely on $Q_{o u t}$ will lead to an expression relating tank water depth $(h)$ to outflow discharge $\left(Q_{\text {out }}\right)$. However, analytically solving this equation would prove cumbersome due to the sinusoidal functions involved. An alternative solution was found that consisted in rewriting equation 8 into a minimization problem. Incorporating equation (1) into equation (9) implies:

$h=h_{c}+\frac{K+1}{2} D_{h c}$

Rewriting equation 10 into the form of an objective function (obj.fun) gives:

$\operatorname{obj} \cdot f u n\left(h_{c}\right)=\left(h-h_{c}-\frac{K+1}{2} D_{h c}\right)^{2}$

For a given value of $h$, finding the value of $h_{c}$ that minimizes the objective function makes it possible to compute the outflow discharge $\left(Q_{\text {out }}\right)$ using equation 1 . Once this relation has been established, it can be associated to the septic tank mass balance equation to build a time-dependent model. For a septic tank, the water mass balance can be written as:

$S \frac{d h}{d t}=Q_{\text {in }}-Q_{\text {out }}$

where $S$ is horizontal surface of the septic tank at the level of the invert of the outflow pipe $\left[\mathrm{L}^{2}\right]$, and $Q_{\text {in }}$ is inflow rate $\left[\mathrm{L}^{3} \mathrm{~T}^{-1}\right]$.

After an explicit discretization, equation 12 becomes:

$S \frac{h(t+\Delta t)-h(t)}{\Delta t}=Q_{\text {in }}(t)-Q_{\text {out }}(t)$ 
The value of $Q_{i n}(t)$ is an input while the value of $Q_{o u t}(t)$ needs to be estimated (except for the initial value). This is carried out by minimizing the objective function (11) at time $t$. Figure 3 schematizes the basic computation steps.

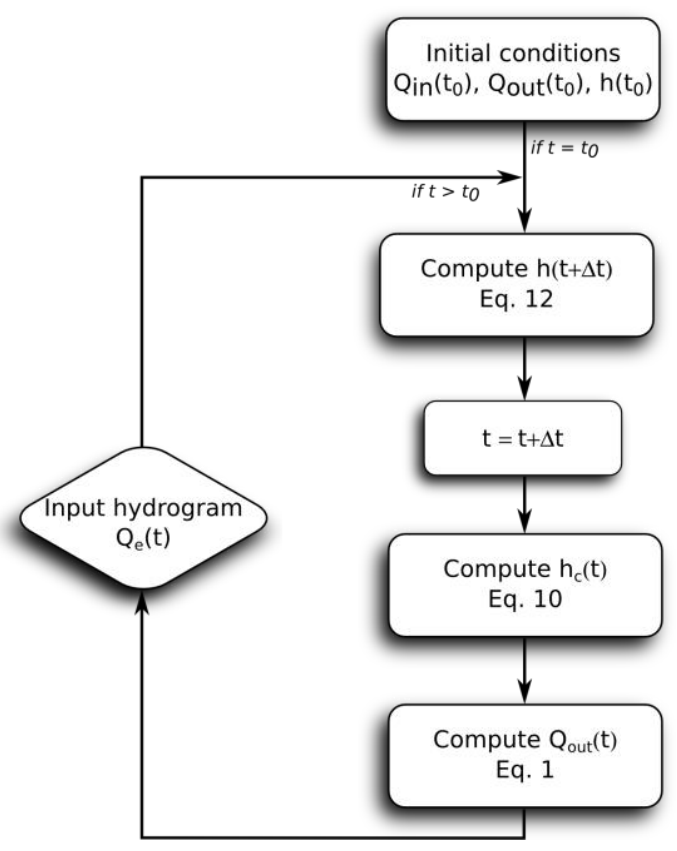

Figure 3. Computation steps

\section{Model implementation}

The model was implemented in $\mathrm{R}$ ( $\mathrm{R}$ Core Team, 2013). The method used for minimizing the objective function is a combination of golden section search and successive parabolic interpolation (Brent, 1973). Accuracy was set to $1 \times 10^{-10} \mathrm{~m}$.

\section{Practical test cases}

This technical note presents three test cases. (1) It is often assumed that the largest inflow rate for a septic tank (if properly disconnected from rainwater) corresponds to the emptying of a bath (200 litres in 3 minutes). (2) In France, new treatment systems require authorization before being commercialized. Since 2009, this authorization is given based on the results of normalized experiments (AFNOR, 2013) carried out by accredited laboratories. Feeding of the wastewater treatment system during these normalized experiments is carried out according to a distribution of the daily hydraulic load that is based on the assumed consumption of a typical household. Based on this distribution, a synthetic hydrograph was generated, corresponding to a two person-household. Daily hydraulic load was estimated at 84 L/pers./day according to Cauchi \& Vignolles (2012). (3) Butler \& Graham (1995) and Butler \& Gatt (1996) presented synthetic hydrographs of wastewater discharge in person-equivalents. Despite the fact that these studies were done on sewage, they are often cited as a benchmark for on-site wastewater treatment systems due to the lack of input hydrographs in this 
domain (Roland et al., 2009). Here, we used the one presented in Butler and Gatt (1996) as an input in our model. The daily hydrograph was pre-normalized so that daily hydraulic load is the same as in case 2. For all three test cases, the characteristics of the septic tank are the same, i.e. a $4 \mathrm{~m}^{2}$ area at the invert of the outflow pipe (100 $\mathrm{mm}$ in diameter) that corresponds to a commercial standard.

Figure 4 presents the results. A single event, like a bath emptying (case a), is considerably smoothed by the septic tank. The outflow discharge reaches only $57 \%$ of the inflow rate at the end of loading. Many treatment systems (e.g. sand filters) downstream of the septic tank have gravity-driven distribution systems and therefore depend on inflow velocity to ensure an even distribution. If the septic tank significantly smoothes its outflow discharge, this could affect the quality of hydraulic distribution in the treatment system. When applied to more averaged hydrographs such as those obtained synthetically based on daily hydraulic load and typical household water usage (AFNOR, 2013; case b) or those experimentally observed at sewer level (Butler \& Gatt, 1996; case c), the smoothing effect tends to be less significant: mean outflow discharges are only $0.6 \%$ and $3.75 \%$ lower than mean inflow rates for the second and third test cases, respectively. In these cases, the septic tank only induces a lag in the propagation of the hydrograph. In addition, case $b$ shows that the septic tank may help ensure a better spreading of hydraulic load over the day.

Evaluation of septic tank buffering on effluent distribution over the secondary treatment unit would requires better measurements of the inlet hydrograph with a small time resolution. The hydrograph suggested by (AFNOR, 2013) is too averaged and actually presents a shape close to the observed in sewers. Patel et al. (2008) measured outflow at the inlet of gravity distribution devices (after the septic tank) and concluded that the most common flow rates were between 0.0016-2.0.03 $1 \mathrm{~h}^{-1}$ with peak values up to $0.21 \mathrm{~h}^{-1}$. For secondary treatments that are not fed by gravity, the septic tank buffer effect may help to ensure a better spreading of the influent over time. Furthermore, the current model could be easily applied to septic tank alternative designs such as tank in series and tank in parallels as they are already widespread in USA and tend to develop in Europe. A sensitivity analysis on parameters $S$ and $D$ could also indicate which one influence the most buffer effect and lag time.

Finally, we would like to stress that not only septic tank induces a buffer effect. Pipes, conducting flow to and out of the septic tank, may also be of importance regarding their diameter (typically 100 $\mathrm{mm})$. 

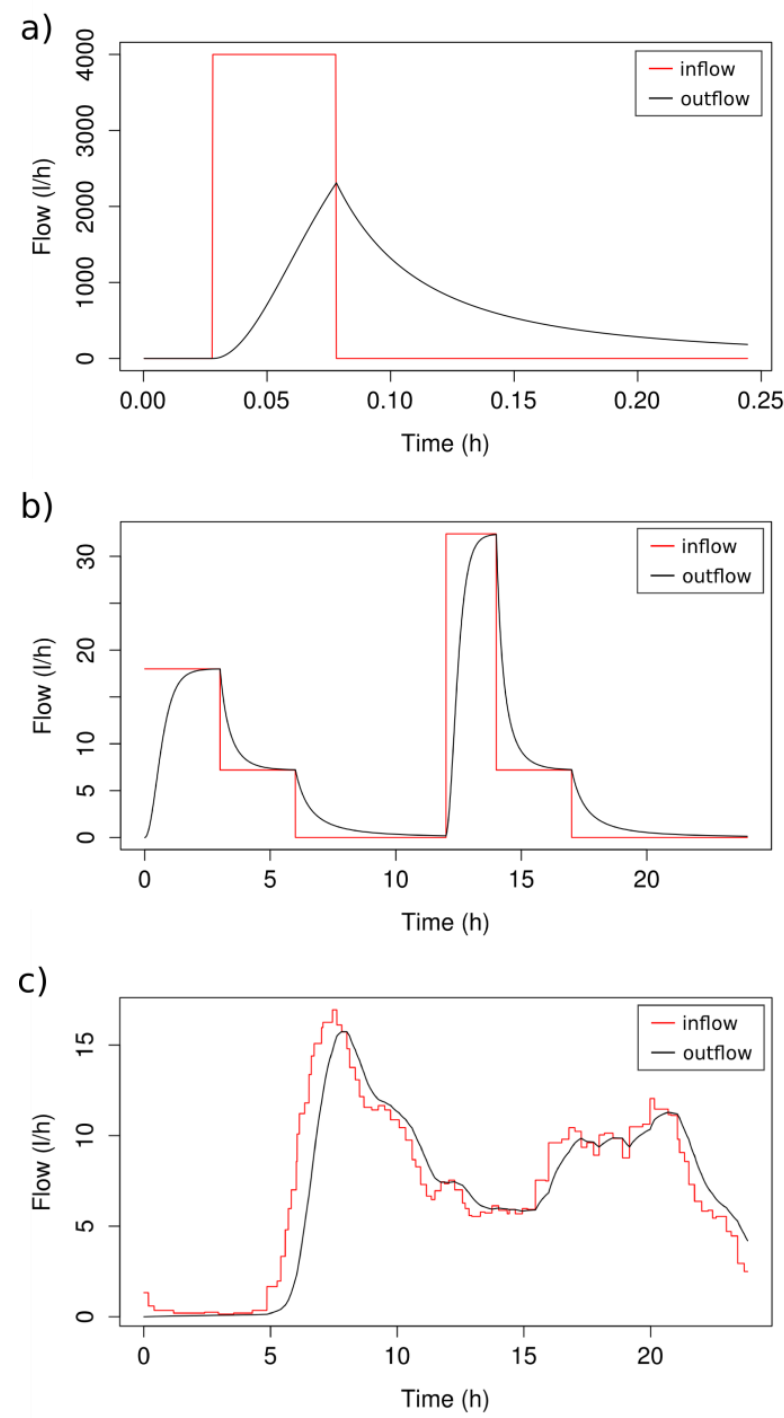

Figure 4. Inflow and outflow hydrographs for three test cases: a) bath emptying, b) synthetic daily dataset, c) dry weather sewage flow (Butler \& Gatt, 1996)

\section{Conclusions}

154 We built a simple mechanistic model suitable for modeling the hydraulic buffering induced by a septic tank. The only constant in the model, i.e. the loss coefficient, was calibrated using deterministic CFD modeling. Results highlight significant modulation of flow in single relatively large events such as a bath emptying. However, on smoother hydrographs, such as those currently available for characterizing a household effluent, the flow modulation only adds a lag time into the influent hydrograph. As we progressively gain more knowledge on the actual shape and amplitude of the hydrograph at the inlet of a septic tank, this simple tool could prove be useful for modeling septic tank outflow and its impact on the spread of wastewater over the treatment unit in configurations based on gravity-driven distribution. 


\section{References}

164

165

166

167

168

169

170

171

172

173

174

175

176

177

178

179

180

181

182

183

184

185

186

187

188

189

190

191

AFNOR (2007). XP DTU 64.1. Mise en œuvre des dispositifs d'assainissement non collectif (dit autonome). [in French]

AFNOR (2013) NF EN 12566-3. Petites installations de traitement des eaux uses jusqu'à 50 PTE partie 3 : stations d'épuration des eaux usées domestique prêtes à l'emploi et/ou assemblées sur site. [in French].

Brent, R. (1973). Algorithms for Minimization without Derivatives. Englewood Cliffs N.J., PrenticeHall.

Bridson-Pateman, E., Hayward, J., Jamieson, R., Boutillier, L., Lake, C. (2013). The effects of dosed versus gravity-fed loading methods on the performance and reliability of contour trench disposal fields used for on-site wastewater treatment. Journal of Environmental Quality 42(2): 553-561.

Butler, D., Graham, N. (1995). Modeling dry weather wastewater flow in sewer networks. Journal Of Environmental Engineering 121(2): 161-173.

Butler, D., Gatt, K. (1996). Synthesising dry weather flow input hydrographs: A Maltese case study. Water Sci. Technol. 34 (3-4): 55-62.

Cauchi, A., Vignolles, C. (2012). Characteristics of raw water from the individual house. L'eau, l'industrie, les nuisances. 354: 91-95. [in French].

Gill, L.W., O’Luanaigh, N., Johnston, P.M., Misstear, B.D.R., O’Suilleabhain, C. (2009). Nutrient loading on subsoils from on-site wastewater effluent, comparing septic tank and secondary treatment systems. Water Research 43: 2739-2749.

Hager W. H. (1999). Wastewater hydraulics. Springer.

OpenFOAM (2013). OpenFOAM - The open source CFD toolbox - User guide. OpenFOAM Foundation.

Patel, T, O’Luanaigh, N., Gill, L.W. (2008). A comparison of gravity distribution devices used in onsite domestic wastewater treatment systems. Journal of Water, Air \& Soil Pollution 191: 55-69.

R Core Team (2013). R: A language environment for statistical computing. R Foundation for Statistical Computing, Vienna, Austria, URL http://www.R-project.org/.

Roland, L. (2009). Comparative analyses of seepage: clogging tools for the diagnosis. Université Montpellier II, Sciences et Techniques du Languedoc, PhD Thesis, 224 pp. [in French]. 
192 Vazquez, J., Zug, M., Bellefleur, D., Grandjean, B., Scrivener, O. (1999). Use of neural network to 193 apply the Muskingum model to sewer networks. Journal of Water Science 12(3): 577-595.

194 Winstanley, H.F., Fowler, A.C. (2013). Biomat development in soil treatment units for on-site 195 wastewater treatment. Bulletin of Mathematical Biology 75: 1985-2001. 